\title{
Men's sexual and reproductive health in the situation of HIV-serodiscordance
}

\author{
Saude sexual e reprodutiva do homem com HIV em situação de sorodiferença \\ Salud sexual y reproductiva del hombre con VIH en situación de serodiscordancia
}

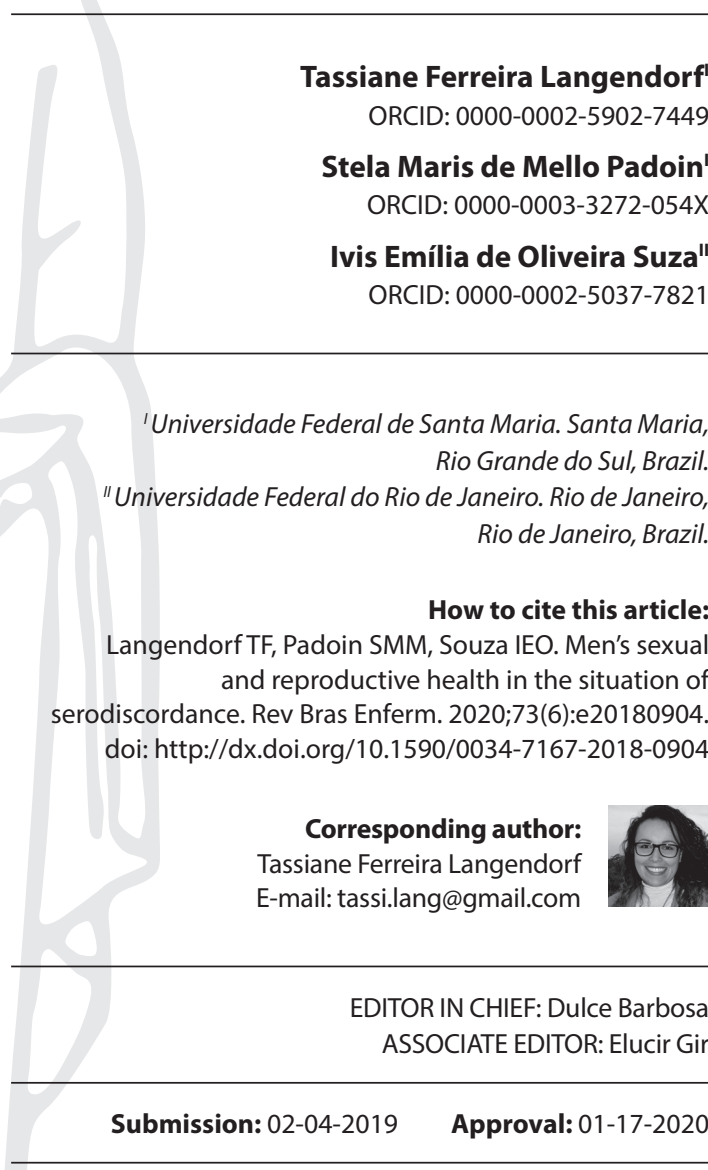

\begin{abstract}
Objective: to know men's perspective in face of reproduction in the situation of HIV-serodiscordance. Method: qualitative study developed in a university hospital in Southern Brazil. Unstructured in-depth interviews were conducted with 11 men living with HIV and a thematic content analysis was performed. Results: men expressed not wanting to have children and that this pregnancy was different. They showed concerns related to the vertical transmission of HIV, sexual and reproductive rights and responsibility in the exercise of parenthood. Final considerations: men's perspective is influenced by their role in the family, which is historically and culturally determined, and by the concerns about infection, which are socially determined and entail their understanding of reproductive rights and their participation in care. In services, men's perspective must be considered in the planning and implementation of health care actions by supporting their participation in the exercise of fatherhood.

Descriptors: Sexual Health; Reproductive Health; Human Rights; Men's Health; HIV.
\end{abstract}

\section{RESUMO}

Objetivo: conhecer a perspectiva do homem diante da reprodução na situação de sorodiferença para o HIV. Método: investigação qualitativa desenvolvida em hospital universitário no Sul do Brasil. Foi realizada entrevista não estruturada em profundidade com 11 homens que vivem com HIV e desenvolvida análise de conteúdo temática. Resultados: expressaram que não queriam ter filhos e que essa gestação é diferente. Demonstraram preocupações relacionadas à transmissão vertical do HIV, aos direitos sexuais e reprodutivos e à responsabilidade no exercício da paternidade. Considerações finais: a perspectiva do homem é influenciada pelo seu papel na família, determinado histórico e culturalmente, e pelas preocupações da infecção, determinadas socialmente, o que implica na sua compreensão do direito reprodutivo e sua participação no cuidado. Há necessidade de os serviços considerarem a perspectiva do homem no planejamento e implementação de ações de atenção à saúde, apoiando a sua participação no exercício da paternidade.

Descritores: Saúde Sexual; Saúde Reprodutiva; Direitos Humanos; Saúde do Homem; HIV.

\section{RESUMEN}

Objetivo: conocer la perspectiva del hombre delante de la reproducción en la situación de serodiscordancia frente al $\mathrm{VIH}$. Método: investigación cualitativa, desarrollada en un hospital universitario ubicado en el Sur del Brasil. Fue realizada entrevista no estructurada en profundidad con 11 hombres con VIH y se ha usado el análisis de contenido en la modalidad temático. Resultados: los hombres expresaron que no querían tener hijos y que esto embarazo fue diferente. Demostraron preocupación y culpa, en especial relacionadas a la transmisión vertical del $\mathrm{VIH}$, a los derechos sexuales y reproductivos y la responsabilidad en el ejercicio de la paternidad. Consideraciones finales: la perspectiva del hombre tiene influencia por su papel en la familia, el cual es determinado histórico y culturalmente, e por las preocupaciones de la infección, determinadas socialmente, que tienen implicaciones en su comprensión del derecho reproductivo y su participación en el cuidado. En los servicios, la perspectiva de los hombres debe ser considerada en la planificación e implementación de las acciones de atención a la salud, al apoyar su participación en el ejercicio de la paternidad.

Descriptores: Salud Sexual; Salud Reproductiva; Derechos Humanos; Salud del Hombre; VIH. 


\section{INTRODUCTION}

Historically and culturally, the reproduction and care of children and family were established as activities inherent to women's social role. However, social and economic changes, such as women's insertion and expressive participation in the labor market have changed their role in society and in the family. These have raised spaces for discussions on the decentralization of childcare as women's responsibility and expanded and valued men's participation and involvement in this process ${ }^{(1)}$.

In the Brazilian health field, this expanded focus of care is seen from the efforts of public policies that support men's right to participate in the care of their children, based on reproductive planning. This includes the decision to have children or not, how and when to have them, and the monitoring of pregnancy, childbirth, postpartum and child education ${ }^{(2-4)}$. The legislation supports the presence of the father during labor, delivery and postpartum $^{(5)}$ and guarantees the permanence of mother and baby in joint accommodation, which favors and strengthens the emotional bond between father, mother and child ${ }^{(6)}$.

This context leads to discussions about sexual and reproductive health and includes the problem arising from the diagnosis of HIV infection, which in turn, imposes the need for planning with use of biotechnologies, such as assisted human reproduction $(\mathrm{AHR})^{(7)}$, how to protect sexual transmission ${ }^{(8)}$ and prophylaxis of vertical transmission of the virus when the woman is HIV positive. There is also the need to know the couple's serostatus ${ }^{(9)}$ - seroconcordant, when both live with HIV, or serodiscordant, when only one partner lives with the virus, among other facts.

Given the reproductive autonomy of couples living with HIV, whether serocondordant or serodiscordant couples, certain questions require an answer, because couples want the pregnancy, but fear the infection of the child ${ }^{(10)}$ or the partner. There is also the confrontation of stigma, prejudice and discrimination that socially involve this disease ${ }^{(11)}$, even in the face of a Brazilian response to the AIDS epidemic, politically based on the understanding that health is everyone's right and ensured by the National Health System (Brazilian SUS).

This policy allowed the structuring of a universal access program for prevention, treatment and healthcare in all its dimensions ${ }^{(12)}$, what has shown to be a necessity for this population and instigated the understanding from the perspective of reproductive rights and inclusion of people living with $\mathrm{HIV}^{(13)}$.

In this perspective, a survey of 162 infected men showed that $67(41.4 \%)$ reported the intention to have a child, out of which 53 reported their main reason was the desire to start a family. This intention maintained a statistically significant association with the fact of wanting to have children before the HIV diagnosis. In conclusion, the study showed the intention of paternity remains in many men, even after being diagnosed with HIV ${ }^{(14)}$.

Regarding this specificity involving reproduction in the HIVserodiscordant situation, a study showed that couples start to manage their difficulties related to intimacy, the possibility of HIV transmission to the seronegative partner and possible negative impacts on the experience of sexuality ${ }^{(15)}$. A study points to a greater need for dialogue between the actors involved in decisions, health service users and professionals committed to reproductive healthcare, including planning a safe conception ${ }^{(16)}$. Such factors refer to the need to implement prevention strategies for the HIV-seronegative partner in serodiscordant couples ${ }^{(17)}$.

\section{OBJECTIVE}

To know the man's perspective regarding reproduction in the HIV-serodiscordant situation.

\section{METHODS}

\section{Ethical aspects}

This research was approved by the Research Ethics Committee of the Universidade Federal de Santa Maria and the international ethical requirements of the Declaration of Helsinki were fulfilled. Participants signed the Informed Consent (IC), which contained clarifications about the study and guarantee of privacy. In order to preserve the anonymity of participants, statements were alphanumerically encoded $(\mathrm{H} 1, \mathrm{H} 2, \mathrm{H} 3$...).

\section{Type of study}

A qualitative study in which was used the Consolidated Criteria for Reporting Qualitative Research (COREQ) tool.

\section{Methodological procedures}

\section{Study scenario}

A university hospital that is reference for the care of people living with HIV, located in a city in the inlands of the State of Rio Grande do Sul, Brazil. Different departments of the hospital were used as setting for the study, namely: clinics of adult infectious diseases, prenatal and childcare, the Medicine Dispensing Unit and the Epidemiological Surveillance Center.

\section{Data collection and organization}

The field stage was conducted from September 2013 to May 2014 with participation of 11 serodiscordant couples. Inclusion criteria were being heterosexual and having experienced the partner's pregnancy. In-depth, unstructured interviews were conducted based on the following guiding question: How was your experience of having this child? When couples did not highlight the serodiscordance in their testimony, there was emphatic reinforcement: How was it for you to have this child being a serodiscordant couple? Interviews were closed when the objective of the study was answered. To this end, the analysis started during the interviews.

In order to meet the study objective, only the testimonies of men were analyzed after re-reading the data that comprised the research corpus of a matrix project focused on issues inherent to the reproduction of serodiscordant couples.

\section{Data analysis}


Data were analyzed through the development of content analysis phases, thematic modality ${ }^{(18)}$. The procedures developed in the study are described below (Chart 1).

Chart 1 - Data analysis process, Santa Maria, Rio Grande do Sul, Brazil, 2018

\begin{tabular}{|l|l|}
\hline $\begin{array}{l}\text { Analysis } \\
\text { phase }\end{array}$ & Description of analytical procedure \\
\hline Pre-analysis & $\begin{array}{l}\text { First contact with the material obtained in the interviews } \\
\text { was by listening to recordings. Literal transcription } \\
\text { by the researcher who developed the technique for } \\
\text { data collection. Skim reading with the intention of } \\
\text { familiarization with the text and constitution of the corpus. }\end{array}$ \\
\hline $\begin{array}{l}\text { Exploration of } \\
\text { material }\end{array}$ & $\begin{array}{l}\text { Sequential and exhaustive reading in order to identify } \\
\text { words and expressions (recording units) and group } \\
\text { them (nuclei of meaning) in order to give meaning } \\
\text { to the objective of study. It resulted in two thematic } \\
\text { categories: HIV versus sexual and reproductive rights; } \\
\text { and Participation of men in care. }\end{array}$ \\
\hline $\begin{array}{l}\text { Treatment of } \\
\text { results and } \\
\text { interpretation }\end{array}$ & $\begin{array}{l}\text { In line with the objective of the study, inferences } \\
\text { and interpretations were proposed, with sexual and } \\
\text { reproductive rights as an analytical category. }\end{array}$ \\
\hline
\end{tabular}

\section{RESULTS}

Participants in this investigation presented the characteristics related to the object of study that were questioned during the interviews of 11 (eleven) men (Table 1). Among participants, four (4) were infected with HIV. Regarding the couple's serostatus at the time of fertilization, eight (8) men were aware of the serodiscordance in their married life and three (3) were unaware of the serodiscordance, because the positive status of their partners was discovered during prenatal care. After pregnancy, two (2) partners became HIV positive, hence characterizing two (2) seroconcordant couples at the time of the interview. Regarding the marital relationship, ten (10) started before their partner's HIV diagnosis and one (1) started after the diagnosis. Regarding reproductive planning, all men reported not wanting their partner's pregnancy. A couple (man was HIV positive) opted for assisted human reproduction after the woman convinced the man to have a child.

For the analysis, in the first thematic category were grouped the HIV infection condition and reproductive rights issues. It was composed of four nuclei of meaning that converge with statements presented as illustrative synthesis (Chart 2).

The second thematic category brought together the issue of men's participation in care with the prophylaxis of vertical transmission and care for the woman and the child. It was composed of two nuclei of meaning that converge with statements presented as illustrative synthesis (Chart 3).
Chart 2 - Nuclei of meaning and recording units of the 'HIV versus reproductive rights' thematic category

\begin{tabular}{|c|c|}
\hline Nuclei of meaning & Recording units \\
\hline $\begin{array}{l}\text { Did not want to } \\
\text { have children }\end{array}$ & $\begin{array}{l}\text { It was very difficult, we didn't even know where to start } \\
\text { and we sought medical help at a fertilization clinic [...] } \\
\text { At first, I didn"t want it. (H1) } \\
\text { The condom broke [...] then, we found out she was } \\
\text { pregnant [...] We were obsessively careful... [...] } \\
\text { condoms always [...] I told her when we met "Hey, kids } \\
\text { no way", we can only do it using condoms. (H5) } \\
\text { I kind of didn't want it, I didn't really want it } \\
\text { [pregnancy] ... But she said "no, it's false [HIV test } \\
\text { result], and I don't have it" [...] Then, I said no, no, let's } \\
\text { wait. (H6) }\end{array}$ \\
\hline $\begin{array}{l}\text { It is not like a } \\
\text { normal pregnancy }\end{array}$ & $\begin{array}{l}\text { Everything becomes difficult, everything, everything, } \\
\text { everything. Nothing is as normal, everything has to be } \\
\text { very planned... until it happens, it's not like that and } \\
\text { "ahh, I'll do it.". No, it has to be very planned. (H1) } \\
\text { Yeah, it was very complicated [...] nine months, she } \\
\text { started taking the medicine correctly [...] everything was } \\
\text { done accordingly [...] In the end, we were very satisfied } \\
\text { because it all went well [...] everything we went through, } \\
\text { all the effort has paid off. (H3) } \\
\text { And especially knowing that he does not have [HIV], for } \\
\text { me it is very good. (H4) } \\
\text { How can we not panic, to have a seropositive child. (H5) } \\
\text { Support her treatment, as much as you can to see if the } \\
\text { child did well. (H7) }\end{array}$ \\
\hline $\begin{array}{l}\text { Self-blame for the } \\
\text { child's health }\end{array}$ & $\begin{array}{l}\text { The guilt I think, is that we were going cause a problem } \\
\text { for him, without him having the option to choose [...] } \\
\text { that would be my regret [...] But knowing these days } \\
\text { that you can give birth to a child and knowing she } \\
\text { can get infected [does not want to go through this } \\
\text { situation again]. (H2) } \\
\text { We wouldn't be able to have peace if [the child] was } \\
\text { born HIV positive. (H3) } \\
\text { Regardless of anything that happens to me, I want to } \\
\text { have an operation [vasectomy] [...] we will not run the } \\
\text { risk of causing suffering to another child in the future. } \\
\text { (H9) }\end{array}$ \\
\hline Prejudice & $\begin{array}{l}\text { Imagine a child being born and when reaching an } \\
\text { understanding, discovering "oh, my father and mother } \\
\text { infected me, got me contaminated" [...] think about } \\
\text { it, how would his mind be, when he knew [there is } \\
\text { prejudice]. (H2) } \\
\text { We don't bring that up much [...] people have prejudice } \\
{[. . .] \text { I prefer that the two of us know [...] it stays between }} \\
\text { us, we try to tell, no matter how much you trust the } \\
\text { person. (H8) } \\
\text { It is difficult for people to understand about it, there is a } \\
\text { lot of prejudice [...] / don't want my son to know, to avoid } \\
\text { the mockery. (H11) }\end{array}$ \\
\hline
\end{tabular}

Table 1 - Information on participants' serological and reproductive status, Santa Maria, Rio Grande do Sul, Brazil, 2018

\begin{tabular}{|c|c|c|c|c|c|c|c|c|c|c|c|}
\hline \multirow{2}{*}{ Variables } & \multicolumn{11}{|c|}{ Participants } \\
\hline & H 1 & H 2 & H 3 & H 4 & H 5 & H 6 & H 7 & H 8 & H 9 & H 10 & H 11 \\
\hline Serostatus & POS & POS & NEG & NEG & POS & POS & NEG & NEG & NEG & NEG & NEG \\
\hline Contraceptive method & $\mathrm{N} / \mathrm{A}$ & OC & $\mathrm{S} / \mathrm{I}$ & OC and C & $\mathrm{C}$ & $\mathrm{N} / \mathrm{A}$ & $\mathrm{C}$ & $\mathrm{N} / \mathrm{A}$ & OC & $\mathrm{S} / \mathrm{I}$ & $\mathrm{OC}$ \\
\hline Planned pregnancy & Yes & No & No & No & No & No & No & No & No & No & No \\
\hline Type of conception & AHR & Natural & Natural & Natural & Natural & Natural & Natural & Natural & Natural & Natural & Natural \\
\hline Couple's serostatus at fertilization & SD & SD & SD & SD & SD & SD & SD & D & SD & U & SD \\
\hline Serodiscordant pregnancies & One & One & Two & Two & One & One & One & One & Two & One & Three \\
\hline Child's serostatus & NEG & NEG & NEG & NEG & NEG & NEG & NEG & $\mathrm{N} / \mathrm{O}$ & NEG & NEG & $\mathrm{N} / \mathrm{O}$ \\
\hline
\end{tabular}


Chart 3 - Nuclei of meaning and recording units of the 'participation of men in care' thematic category

\begin{tabular}{|l|l|}
\hline Nuclei of meaning & \multicolumn{1}{|c|}{ Recording units } \\
\hline support and care & $\begin{array}{l}\text { I'm quite happy, because in these nine months of her } \\
\text { pregnancy I supported her a lot in this part [...] to be } \\
\text { able to help her and then help my son, helping one } \\
\text { and helping the other. (H3) } \\
\text { And we have to take care of each other, help each } \\
\text { other and get by. (H4) } \\
\text { Support her, support her treatment [...] If she needs } \\
\text { to go to the doctor, right, go with her [in consulta- } \\
\text { tions], that she was being treated. (H7) }\end{array}$ \\
$\begin{array}{ll}\text { I deal with the fact that we are a couple that has a } \\
\ldots . \text { How can I say ... We have a characteristic that we } \\
\text { both have to be careful. (H9) } \\
\text { I've always been by her side [F11]. (H11) }\end{array}$ \\
\hline $\begin{array}{l}\text { Fatherhood } \\
\text { There is no way to translate this feeling [of being a } \\
\text { father]. (H1) } \\
\text { Healthy, strong boy ... so for us it's crazy good, really } \\
\text { satisfied. (H3) } \\
\text { It's my life [the daughter] [...] how would I have a } \\
\text { child? how would I think I could have. (H5) } \\
\text { Igo to work, come back and I just come to play with } \\
\text { her, you know, give her attention. (H8) } \\
\text { Ialso have a reason to show myself that I must carry } \\
\text { on, I have a daughter, I have a son [...] I have many } \\
\text { reasons, nowadays, not to get discouraged. (H9) }\end{array}$ \\
\hline
\end{tabular}

The interpretations were made from the thematic categories and in line with the study objective by considering sexual and reproductive rights as the analytical category.

\section{DISCUSSION}

\section{Exercise of sexual right and denial of reproductive right}

From men's perspective, experiencing hiv-serodiscordance in married life guided their reproductive choices and desires, which included behaviors for reducing HIV transmission ${ }^{(17,19)}$. In view of this situation, participants reported not wanting/not planning the pregnancy because of HIV infection, whether their own or that of their partner. In a study with 102 women, the majority (63.7\%) no longer intended to have children ${ }^{(9)}$. In the present study, as the pregnancy had not been planned, it was a surprise even for those who underwent assisted human reproduction, because they did not believe it would work. When they realized, the woman was already in the first trimester of pregnancy and the child was already a fact in their lives. They attributed pregnancy to the failure in contraceptive methods of choice, such as ineffectiveness of oral contraceptives and a broken male condom. This reflects the lack of an enlightening approach to reproductive planning by health professionals in primary and specialized care services.

When participants reported the desire to have a child, it was attributed to the woman, who insisted and sought resources for assisted reproduction. Reproductive planning and the choice made by women is directly influenced by psychosocial and cultural issues ${ }^{(10,20)}$. For men participating in this study, this implied acceptance of pregnancy and adaptation to the care needed during pregnancy in the context of HIV. In addition to acceptance, they highlighted joy, the desire to live in harmony and face new social roles ${ }^{(21)}$.

Upon accepting, men understood it would be a normal pregnancy, as they would need care to prevent the transmission of HIV to their child. In a study that evaluated the cascade of care for the reduction of vertical transmission of HIV in six Brazilian states, failures were identified in all healthcare points, as well as the need for a connection between referral and primary care services, focusing on family care $^{(22)}$. Action planning in health services also involves establishing bonds and trust between users and professionals with the aim to minimize the dimensions related to prejudice and stigma that are still present in this relationship. Sometimes, difficulties are faced with the disclosure of diagnosis to the health team and access to the service, and imply blaming, when professionals interpret that pregnancy could or should be avoided ${ }^{(23)}$.

In the present study, men felt responsible for exposing their child to a situation of vulnerability to HIV infection and guilty for the possibility of getting them infected. In view of this, they stated not wanting a next pregnancy, which reflects a certain lack of knowledge of their reproductive rights regarding safe conception ${ }^{(10)}$. Information about the risks of virus transmission from knowledge of viral load values (detectable or undetectable) would be relevant to minimize guilt and fear. Men's decision of not having any more children goes against the feeling of paternity experienced positively in situations where there is no HIV infection and reflects the social expectation of male virility manifested in fulfilling their social role of reproducing the species ${ }^{(20)}$.

In a study developed to analyze the reproductive aspects and the knowledge of family planning in the face of AIDS diagnosis, it was found that women believed they could have children. However, a third of them revealed they had received reproductive planning guidance and were unaware of prophylaxis measures for vertical HIV transmission. Regarding the serology of couples and conception, women believed seroconcordant couples could have children and serodiscordant couples could not ${ }^{(9)}$.

Guilt, based on insecurity and fear of the child's illness, reflects the lack of knowledge about the prophylaxis of vertical HIV transmission, which implies the need for clarifications for reproductive planning and, consequently, breaking the silence about the couple's serostatus. Disclosing the diagnosis of seropositivity is a difficulty faced by people living with viruses for fear of non-acceptance and the possibility of breaking up emotional relationships. Feelings of guilt and shame can lead to social isolation ${ }^{(11,14)}$.

Despite such feelings, stigmatization, isolation and lack of reproductive planning information, reproduction occurs. The epidemiological surveillance bulletin of the HIV epidemic in Brazil shows that in the period from 2000 to June $2017,108,134$ pregnant women with HIV were notified, with a slight upward trend in recent years ${ }^{(24)}$. The lack of information about the number of pregnancies in serodiscordant couples (seropositive man) in official notifications is noteworthy. This reflects the need for a response from public policy in relation to reproductive rights of people living with HIV.

This gap in epidemiological data has a negative impact on reproductive healthcare planning. In addition, it is important to know these couples and understand their reproductive needs and demands ${ }^{(25)}$. Research with health professionals showed they have knowledge about practices of safe conception and prevention of 
HIV transmission among serodiscordant couples. However, these professionals do not always discuss such information and when they do, they almost always address women ${ }^{(26)}$.

\section{The perspective of paternity as a right mediated by care}

Self-care and care for the other are associated with the feminine sphere and based on cultural issues. The literature on reproductive rights and gender issues ${ }^{(27)}$ seeks to rescue the man's role in this period ${ }^{(2)}$, including labor and childbirth ${ }^{(28-29)}$. In the present study, participants' manifestation of wanting to accompany the pregnancy and that both should be responsible for care, refers to the interpretation of men's interest in being included in the care actions, despite a culture that does not yet recognize them, given its focus on the mother-baby dyad ${ }^{(30)}$.

This user is part of a movement against hegemony, in which health professionals are being invited to a certain repositioning in health actions, based on principles and policies for men's involvement in prenatal care. This was pointed out in the consensus established by specialists in the area for male care focused on sexual health, reproduction and fatherhood ${ }^{(31)}$.

The discussion about men's involvement in prenatal care expands to studies that aim to characterize paternal involvement in childcare. The aim of a study with 81 parents was to characterize this involvement at different socioeconomic levels. The conclusion was that these levels revealed no differences in this characterization and the new conceptions and expectations of paternity are shared in the different strata of society. Another aspect involves changes in women's social role, such as their qualification and insertion in the labor market, when greater equality of responsibility is expected between men and women in relation to raising children, which affects the exercise of fatherhood ${ }^{(32)}$. International studies also show the influence of women's education on paternal care time ${ }^{(33-34)}$.

In the present study, the time spent with paternal care reflects the realization of being a father in a situation of hiv-serodiscordance and the responsibility in exercising fatherhood. In a study conducted with men who experienced the post-birth period, having a child and being able to exercise fatherhood was considered a personal gain experienced with joy, satisfaction and realization of being a father, which implied in personal and family life maturation. In addition, it implied in greater responsibility for one's own life and for the family life ${ }^{(35)}$.

\section{Study limitations}

The limitation of this study refers to the geographical factor, since a single municipality does not allow generalizations regarding the topic addressed.

\section{Contributions to the field of nursing, health or public policy}

The evidence demonstrated in this study clarifies the persisting need to bring health professionals closer to discussions on reproductive planning of couples living with HIV, and to plan healthcare actions that strengthen the bond with men and enable their participation in the exercise of fatherhood. Such issues are linked to the role of nursing in human reproduction, which is to promote, maintain or recover health in the field of sexual and reproductive rights.

\section{FINAL CONSIDERATIONS}

From men's perspective, the occurrence of the reproductive process in serodiscordance mobilizes feelings that discourage them and promote thoughts of the impossibility of having children, which results from misinformation or lack of information about the topic. Participants also expressed concern and guilt for the social response to the HIV epidemic, especially those related to sexual and reproductive rights.

These facts stem directly from the insufficient implementation and articulation of reproductive planning policies, which are fundamental for couples, especially hiv-serodiscordant couples, having a calm and safe experience of the reproductive process without the risk of HIV transmission. The perspectives of study participants reflect the historical and cultural construction of men's social role of providers and responsible for the wellbeing of family members.

The evidence points to the need to include men as subjects who can be protagonists and responsible in this care process, as long as they receive support from health professionals in issues related to sexual and reproductive healthcare.

\section{FUNDING}

Scholarship from the National Postdoctoral Program of the Coordination for the Improvement of Higher Education Personnel (PNPD / CAPES).

\section{REFERENCES}

1. Abade F, Romanelli G. Paternidade e paternagem em famílias patrifocais. Rev Estud Fem. 2018;26(2):e50106. doi: 10.1590/1806-9584-2018v26n250106

2. Ministério da Saúde (BR). Secretaria de Atenção à Saúde. Política Nacional de Atenção Integral à Saúde do Homem. Brasília: Ministério da Saúde, 2008.

3. Ministério da Saúde (BR). Portaria 1.549, de 24 de junho de 2011. Institui, no âmbito do Sistema Único de Saúde (SUS), a Rede Cegonha. Brasília: Ministério da Saúde, 2011.

4. Ministério da Saúde (BR). Secretaria de Atenção à Saúde. Guia do Pré-Natal do Parceiro para Profissionais de Saúde. Brasília: Ministério da Saúde, 2016.

5. Presidência da República (BR). Lei n.11.108, de 07 de abril de 2005, Altera a Lei no 8.080, de 19 de setembro de 1990, para garantir às parturientes, o direito à presença de acompanhante durante o trabalho de parto, parto e pós-parto imediato, no âmbito do Sistema Único de Saúde - SUS. Brasília, DF, 2005. 
6. Ministério da Saúde (BR). PORTARIA № 2.068, de 21 de outubro de 2016. Institui diretrizes para a organização da atenção integral e humanizada à mulher e ao recém-nascido no Alojamento Conjunto. Brasília: Ministério da Saúde, 2016.

7. Vargas EP, Maksud I, Moás LC, et al. HIV/AIDS, reproductive rights and reproductive technologies: mapping different perspectives. Rev Eletr Com Inf Inov Saúde. 2010;4(5):3-13. doi: 10.3395/reciis.v4i5.482

8. Silva TQC, Szapiro AM. Heterosexuals women in stable relationship: limits of advice on STD/HIV/AIDS. Rev Subjet[Internet]. 2015 [cited 2018 Jul 20];15(3):350-61. Available from: http://pepsic.bvsalud.org/pdf/rs/v15n3/04.pdf

9. Lima ICV, Cunha MCSO, Cunha GH. Reproductive aspects and knowledge of family planning among women with Acquired Immunodeficiency Syndrome. Rev Esc Enferm USP. 2017;51:e03224. doi: 10.1590/s1980-220×2016039403224

10. Matão MLL, Miranda DB, Freitas MIF. Between desire, duty and fear of being a mother after HIV seropositivity. Enferm Glob[Internet]. 2014[cited 2018 Jul 20];13(2):467-80. Available from: http://scielo.isciii.es/pdf/eg/v13n34/pt_enfermeria1.pdf

11. Caliari JS, Teles AS, Reis RK. Factors related to the perceived stigmatization of people living with HIV. Rev Esc Enferm USP. 2017;51:e03248. doi: 10.1590/s1980-220x2016046703248

12. Ministério da Saúde (BR). Recomendações de terapia antirretroviral para adultos vivendo com HIV/aids no Brasil. Versão Preliminar. Brasília: Ministério da Saúde, 2012.

13. Moás LC, Vargas EP, Maksud I. HIV/AIDS and reproduction: an analysis of the legal perspective. Cad. de Pesq.2013 set/dez;43(150):948-67. doi: 10.1590/S0100-15742013000300011

14. Reis CBS, Araújo MAL, Andrade RFV. Prevalence and factors associated with paternity intention among men living with HIV/AIDS in Fortaleza, Ceará. Texto Contexto Enferm. 2015;24(4):1053-60. doi: 10.1590/0104-0707201500003560014

15. Reis RK, Gir E. Living with the difference: the impact of serodiscordance on the affective and sexual life of HIV/aids patients. Rev Esc Enferm USP. 2010;44(3):759-65. doi: 10.1590/S0080-62342010000300030

16. Matthews LT, Burns BF, Bajunirwe F. Beyond HIV-serodiscordance: partnership communication dynamics that affect engagement in safer conception care. PloS ONE [Internet]. 2017[cited 2018 Jul 20];12(9):e0183131. Available from: https://www.ncbi.nlm.nih.gov/ pubmed/28880892.

17. Hallal RC, Raxach JC, Barcellos NT. Strategies to prevent HIV transmission to serodiscordant couples. Rev Bras Epidemiol. 2015;18(Suppl 1):169-82. doi: 10.1590/1809-4503201500050013

18. Minayo MCS. O desafio do conhecimento: pesquisa qualitativa em saúde. São Paulo: Hucitec, 2015.

19. Crankshaw TL, Matthews LT, Giddy J. A conceptual framework for understanding HIV risk behavior inthe context of supporting fertility goals among HIV serodiscordant couples. Reprod Health Matters[Internet]. 2012[cited 2018 Jul 20];20(39-suppl):50-60. Available from: https:// www.ncbi.nlm.nih.gov/pmc/articles/PMC3608509/

20. Cordova FP, Luz AMH, Innocente AP, et al. HIV seropositive women and their partners facing the decision of a pregnancy. Rev Bras Enferm. 2013;66(1):97-102. doi: 10.1590/S0034-71672013000100015

21. Freitas WMF, Coelho EAC, Silva ATMC. Fatherhood: the male experience from a gender focus. Cad Saúde Pública. 2007;23(1):137-45. doi: $10.1590 /$ S0102-311X2007000100015

22. Miranda AE, Pereira GFE, Araújo MAL. Avaliação da cascata de cuidado na prevençãoda transmissão vertical do HIV no Brasil. Cad Saúde Pública[Internet]. 2016 [cited 2018 Jul 20];32(9):e00118215. Available from: http://www.scielo.br/pdf/csp/v32n9/1678-4464-csp-3209-e00118215.pdf

23. Zambenedetti G, Both NS. "A via que facilita é a mesma que dificulta”: estigma e atenção em HIV-Aids na Estratégia Saúde da Família - ESF. Rev Psicol. 2013;25(1):41-58. doi: 10.1590/S1984-02922013000100004

24. Ministério da Saúde (BR). Secretaria de Vigilância em Saúde. Boletim Epidemiológico -Ano V - no 1 - 27a a 53a - semanas epidemiológicas julho a dezembro de 2016. Ano V - no 1 - 01 a a 26a - semanas epidemiológicas - janeiro a junho de 2017. Brasília: Ministério da Saúde, 2017.

25. Langendorf TF, Souza IEO, Padoin SMM. Possibilidades de cuidado ao casal sorodiscordante para o HIV que engravidou. Rev Bras Enferm [Internet]. 2017[cited 2018 Jul 20];70(6):1265-72. Available from: http://www.scielo.br/pdf/reben/v70n6/pt_0034-7167-reben-70-06-1199.pdf

26. Rahangdale L, Richardson A, Carda-Auten J. Provider Attitudes toward Discussing Fertility Intentions with HIV-Infected Women and Serodiscordant Couples in the USA. J AIDS Clin Res [Internet]. 2014 [cited 2018 Jul 20];5(6):1000307. Available from: https://www.ncbi.nlm. nih.gov/pubmed/25221730

27. Scott J. Gênero: uma categoria útil de análise histórica. Educação e Realidade. 1995;20(2):71-99.

28. Santos RS, Caires TLG. Feelings, sensations and emotions of fathers who experienced the birth of their children. Cienc Enferm. 2016;22(1):125-33. doi: 10.4067/S0717-95532016000100011

29. Melo RM, Angelo BHB, Pontes CM. Men's knowledge of labor and childbirth. Esc Anna Nery. 2015;19(3):454-59. doi: $10.5935 / 1414-8145.20150060$

30. Ribeiro CR, Gomes R, Moreira MCN. Meetings and disagreements between men's health, the promotion of participatory parenting and sexual and reproductive health in basic care. Physis: Rev Saude Coletiva. 2017;27(1):41-60. doi: 10.1590/s0103-73312017000100003

31. Gomes R, Albernaz L, Ribeiro CRS. Lines of male care geared to sexual health, reproduction and paternity Ciênc Saúde Colet. 2016;21(5):1545-52. doi: 10.1590/1413-81232015215.26842015 
32. Gomes QS, Alvarenga P. Paternal involvement in families from different socioeconomic status. Psicol Teor Pesqui. 2016;32(3):1-9. doi: $10.1590 / 0102-3772 \mathrm{e} 323216$

33. Reich N. Fathers' Childcare: the difference between participation and amount of time. J Fam Econ Issues [Internet]. 2014 [cited 2018 Jul 20];35(2):190-213. Available from: https://link.springer.com/article/10.1007/s10834-013-9359-y

34. England P, Srivastava A. Educational differences in US parents' time spent in child care: the role of culture and cross-spouse influence. Soc Sci Res. 2013;42(4):971-88. doi: 10.1016/j.ssresearch.2013.03.003

35. Teixeira RC, Mandú ENT, Corrêa ACP. Experiences and health needs of men in the period post-birth of a child Rev Bras Enferm. 2014;67(5):780-7. doi: 10.1590/0034-7167.2014670516 